\title{
PENGARUH KONSENTRASI BUAH NANAS SEBAGAI SUMBER ENZIM BROMELINTERHADAP SIFAT KIMIA DAN ORGANOLEPTIK HIDROLISAT PROTEIN DARI IKAN LELE DUMBO ( Clariasgariepinus)
}

\author{
EMAN DARMAWAN \\ Program Studi Teknologi Pangan \\ Fakultas Sains danTeknologi Universitas Widya Mataram
}

\begin{abstract}
African catfish (Clarias Gariepinus) has the potential to become the raw material for fish protein hydrolysates due to their high protein content and abundant production. Pineapple is a source of protein enzymes. Bromelin enzyme is one of the protease enzymes that can help in accelerating the protein hydrolysis reaction. This study aims to determine the effect of pineapple porridge concentration (Bromelin enzyme) on the chemical and organoleptic properties of protein hydrolyzate from African catfish (Clarias Gariepinus). The experimental design used in this study was a Completely Randomized Design (CRD) with the treatment of pineapple fruit concentrations of $10 \mathrm{~g}, 15 \mathrm{~g}, 20 \mathrm{~g}, 25 \mathrm{~g}$, and $30 \mathrm{~g}$. The parameters observed were water content, protein, fat, carbohydrate, ash, yield, and organoleptic tests. The concentration of pineapple porridge (Bromelin enzyme) significantly affects water content, protein, fat, carbohydrates, and ash. Optimum conditions for hydrolyzing African catfish to protein hydrolyzate are the concentration of pineapple pulp $20 \mathrm{~g}$, water content $80.81 \%$, protein content $72.04 \% \mathrm{db}$, fat content $0.58 \% \mathrm{db}$, carbohydrate $3.05 \% \mathrm{db}$, ash content $13.92 \% \mathrm{db}$, color red hydroxylate (1.65), specific fresh odor (1.85), and neutral taste (2.85), the yield of $13.92 \%$.
\end{abstract}

Keywords: African catfish, bromelin enzyme, and protein hydrolyzate

Ikan lele dumbo gariepinus) memiliki potensimenjadi bahanbakuhidrolisatproteinikankarenakandunganproteintinggidanproduksicukup melimpah. Buah nanas merupakan salah satu sumber enzim protein.EnzimBromelinmerupakansalahsatuenzimproteaseyang dapatmembantudalam mempercepatreaksihidrolisaprotein.Penelitianinibertujuanuntukuntuk mengetahui pengaruh konsentrasi bubur busah nanas (enzim bromelin) terhadap sifat kimia dan organoleptik hidrolisat protein dari ikan lele dumbo (Clarias gariepinus).Rancangan percobaanyang yang digunakan dalam penelitian ini adalah Rancangan Acak Lengkap (RAL) dengan perlakuan konsentrasi buah nanas $10 \mathrm{~g}, 15 \mathrm{~g}$, 20 g, 25 g, dan 30 g. Parameteryangdiamatiadalahkadarair, protein,lemak, karbohidrat,abu,rendemendan uji organoleptik. Konsentrasi bubur buah nanas (enzim bromelin) berpengaruh nyata terhadap kadar air, protein, lemak, karbohidrat dan abu. Kondisi optimum untuk menghidrolisis daging ikan lele dumbo menjadi hidrolisat protein adalah konsentrasi bubur buah nanas $20 \mathrm{~g}$, kadar air 80.81 \%, kadar protein $72.04 \%$ db, kadar lemak $0.58 \%$ db, karbohidrat $3.05 \%$ db, kadar abu $13.92 \%$ db, warna hidrosilat merah (1.65), bau segar spesifik (1.85), dan rasa netral (2.85), rendemen sebesar $13.92 \%$.

Kata Kunci:Lele dumbo, enzim bromelin, dan hidrolisat protein

\section{PENDAHULUAN}

Ikan lele dumbo (Clarias gariepinus) merupakan salah satu jenis ikan yang banyak digemari karena memiliki rasa yang gurih, mengandung nutrisi yang penting bagi tubuh seperti protein, asam lemak omega-3 serta vitamin B kompleks.

Ikan lele dumbo memiliki potensi sebagai sumber protein yang dapat dibuat dalam bentuk hidrosilat protein ikan. Hidrosilat protein ikan merupakan produk 
yang dihasilkan dari perurain protein ikan menjadi senyawa-senyawa berantai pendek karena adanya proses hidrolisis baik oleh enzim, asam maupun basa (Pigot and Tucker, 1990). Produk hidrosilat mempunyai kelarutan pada air yang tinggi, kapasitas emulsinya baik, kemampuan mengembang besar serta mudah diserap tubuh. Hidrosilat protein dapat dimanfaatkan dalam berbagai produk, baik produk makanan, kosmetik/ farmasi, dan sebagainya.Sehingga memiliki potensi nilai ekonomi yang lebih baik lagi.

Enzim bromelin adalah salah satu enzim proteolitik pada nanas yang harganya relatif murah sehingga berpotensi digunakan sebagai enzim pada proses pengolahan hidrolisat protein ikan. Beberapa penelitian menunjukan bahwa enzim bromelin berperan dalam proses hidrolisis ikan. Penelitian Wijayanti etal.(2016). Menunjukan konsentrasi enzim bromelin $6 \%$ dengan waktu hidrolisis selama 6 jam paling optimal dalam proses hidrolisis ikan bandeng, akan tetapi belum pernah dilakukan kajian untuk ikan lele dumbo dengan mengunakan enzim bromelin dari buah nanas. Oleh karena itu perlu dilakukan penelitianlebih lanjut mengenai pengaruh konsentrasi buah nanas (enzim bromelin) terhadap sifat kimia dan organoleptik hidrosilat protein dari ikan lele dumbo (clarias gariepinus). Penelitian ini bertujuan untuk mengetahui pengaruh konsentrasi enzim bromelin terhadap sifat kimia dan organoleptik hidrosilat protein dari ikan lele dumbo (Clarias gariepinus).

\section{METODE PENELITIAN}

\section{Waktu dan Tempat}

Penelitian ini dilaksanakan pada AprilJuli 2019, bertempat di Laboratorium Kimia
Pangan Fakultas Teknologi Pertanian Universitas Widya Mataram.

\section{Bahan dan Alat}

Bahan baku yang digunakan dalam penelitian ini adalah ikan lele dumbo segar dan buah nanas segar. Bahan untuk analisa kimia PA produk E. merck antara lain: adalahK $\mathrm{SO}_{4}$, $\mathrm{MgO}, \mathrm{H}_{2} \mathrm{SO}_{4}$, $\mathrm{H}_{3} \mathrm{PO}_{3}, \mathrm{MgCO}_{3}, \mathrm{NaOH}, \mathrm{CH}_{3} \mathrm{COOH}, \mathrm{HCl}$, $\mathrm{Na}_{2} \mathrm{~S}_{2} \mathrm{O}_{3}, \mathrm{AgNO}_{3}, \quad \mathrm{BaCl}$, heksana, asamasetatglasial,larutan kuprifosfat,larutanbufferdanakuades.

Peralatanyangdigunakanpadapenelitianin iantaralain adalah kain saring, gelas ukur, erlenmeyer dan pendingin tegak,pemanasair(hotplate)denganpengatursu hu, centrifuge

danpengeringbeku(freezedryer), seperangkat peralatan

laboratoriumuntukanalisakimiaprodukhidrolis atikanseperti labuKjeldahl, perangkat alatdestilasi, perangkat alatekstraksi soxlet, oven, desikator, cawan porselin, tanur pengabuan,

kertassaringwhatman,pHmeterdanpengaduk.

\section{Pelaksanaan Penelitian}

Daging ikan lele dumbo yang telak dicincang dengan air (1:4) dan enzim bromelin/bubur buah nanas dengan berbagai konsentrasi (10 g, 15 g, 20 g, 25 g dan 30 g), kemudian dilakukan hidrolisis pada suhu $55^{\circ} \mathrm{C}$. untuk menjaga kesetabilan $\mathrm{pH}$ tetap 7 pada saat proses hidrolisasi berlangsung digunakan $\mathrm{CH}_{3} \mathrm{COOH}$ sebagai pengatur suasana asam dan $\mathrm{NaOH}$ sebagai pengatur suasana basa. Selanjutnya dilakukan penginaktivan enzim pada suhu $90^{\circ} \mathrm{C}$ selama 20 menit, penyaringan, sentrifuse, pada suhu $4^{\circ} \mathrm{C}$, sehingga diperoleh fraksi larutan larutan yang berupa hidrosilat protein ikan. 
Selanjutnya produk hidrolisat ini dilakukan dengan uji proksimat (kadar protein, lemak, air, abu dan karbohidrat), uji organoleptic dan rendemen

Daging Ikan Lele Dumbo

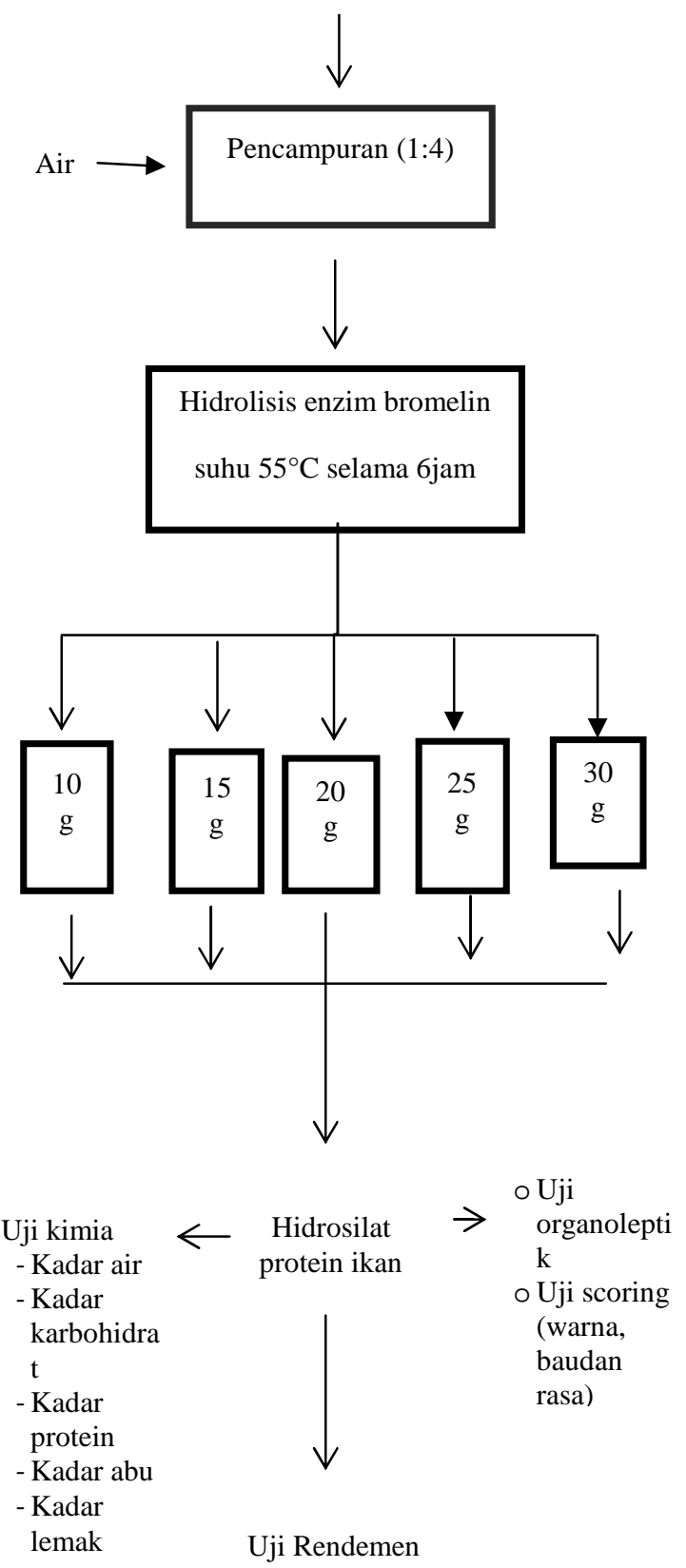

Gambar 1.Daftar alir prooses penelitian pembuatan hidrosilat protein ikan.

\section{Prosedur Analisis}

Analisis proksimat (Slamet., $d k k ., 1989)$.Analisis kadar air, protein, lemak, abu dan karbohidrat (by different).Uji Organoleptik: uji warna, bau dan rasa menggunakan metode scoring test.

\section{Analisis Rendemen}

Rendemen hidrosilat protein ikan lele dumbo dihitung mengacu pada Hadiwiyoto (1993) dengan rumus sebagai berikut:

Rendemen HPI $(\%)=$ berat hidrolisat protein ikan $(\mathrm{g})$ x 100\% Berat daging ikan cincang (g)

\section{Rancangan Perobaan}

Penelitian ini mengunakan metode Rancangan Acak Lengkap (RAL) dengan satu faktor perlakuan yaitu pengaruhkonsentrasi bubur buah nanas.Setiap perlakuan dilakukan tiga kali ulangan.Data yang diperoleh dianalisa dengan Analystof varians (ANOVA) dan bila terdapatperbedaan antara perlakuan dilanjutkan dengan uji lanjut DMRT pada taraf singnifikan 5\%.

\section{HASIL DAN PEMBAHASAN}

\section{Kadar Air}

Hasil analisa ragam menunjukkan perbedaan yang nyata ( $\mathrm{P}>0,05)$ diantara perlakuan penambahan bubur buah nanas pada daging ikan lele dumbo. Rata-rata nilai kadar air (\%) daging lele dumbo dari masingmasing perlakuan dapat dilihat pada Tabel 1.

Tabel 1. Kadar air (\%) daging lele dumbo pada konsentrasi buah nanas. 


\begin{tabular}{|c|c|}
\hline $\begin{array}{c}\text { Konsentrasi Bubur } \\
\text { Buah Nanas }(\mathrm{g})\end{array}$ & Air $(\%)$ \\
\hline 10 & $79.88 \mathrm{~b}$ \\
15 & $80.33 \mathrm{~b}$ \\
20 & $80.81 \mathrm{a}, \mathrm{b}$ \\
25 & $81.20 \mathrm{a}$ \\
30 & $81.64 \mathrm{a}$ \\
\hline
\end{tabular}

Keterangan: Hasil diatas merupakan rerata dari tiga ulangan. Angka yang diikuti dengan notasi huruf yang sama dalam satu kolom menandakan antara perlakuan tidak berbeda nyata pada taraf signifikan 5\%.

Kadar air tertinggi terdapat pada penambahan konsentrasi bubur buah nanas 30 gsebesar $81.64 \%$, sedangkan kadar air terendah terdapat pada kosentrasi bubur buah nanas $10 \mathrm{~g}$ sebesar $79.88 \%$. Menurut Asryani (2007) dalamIsmanto dan Basuki (2017) ektrak buah nanas mampu memecah molekulmolekul protein menjadi lebih sederhana sehingga kemampuan memecah air menjadi lebih kuat. Komponen daging untuk untuk mengikat air sangat erat hubunganya dengan daya ikat oleh protein sebab komponen daging untuk mengikat molekul air sangat tergantung pada banyaknya gugus relatif protein.

\section{Kadar Protein}

Hasil analisa ragam menunjukkan bahwa konsentrasi buah nanas berpengaruh secara nyata terhadap kadar protein daging ikan lele dumbo. Rata-rata kadar protein $\left(\begin{array}{ll}\% & \mathrm{db}\end{array}\right)$ daging lele dumbo dari masing-masing perlakuan dapat dilihat pada Tabel 2.

Tabel 2.Kadar protein $(\% \mathrm{db})$ leledumbo pada konsentrasi buah nanas.

\begin{tabular}{|c|c|}
\hline Konsentrasi Bubur Buah Nanas $(\mathrm{g})$ & Protein $(\% \mathrm{db})$ \\
\hline 10 & $65.41 \mathrm{e}$ \\
15 & $69.49 \mathrm{~d}$ \\
20 & $72.04 \mathrm{c}$ \\
25 & $74.68 \mathrm{~b}$ \\
\hline
\end{tabular}

30

$76.60 \mathrm{a}$

Keterangan : Hasil diatas merupakan rerata dari tiga ulangan. Angka yang diikuti dengan notasi huruf yang sama dalam satu kolom menandakan antara perlakuan tidak berbeda nyata pada taraf signifikan $5 \%$.

Kadar protein tertinggi terdapat pada penambahan konsentrasi bubur buah nanas 30 g sebesar $76.60 \%$ db, sedangkan kadar protein terendah terdapat pada konsentrasi bubur buah nanas $10 \mathrm{~g}$ sebesar $65.41 \% \mathrm{db}$. Hal ini menunjukkan bahwa semakin besar konsentrasi bubur buah nanas yang ditambahkan, maka kadar protein pada daging lele dumbo semakin besar. Menurut Firman (2006) buah nanas merupakan sumber protease dengan konsentrasi tinggi. Enzim bromelin merupakan suatu enzim protease yang mampu memecah protein melalui reaksi hidrolisis, oleh karena itu dapat meningkatkan kadar protein. Enzim bromelin dapat menghidrolisis ikatan peptida dari suatu rantai polipeptida pada protein menjadi molekul yang lebih sederhana yaitu asam amino sehingga lebih mudah dicerna tubuh.

\section{Kadar Lemak}

Berdasarkan hasil penelitian yang dilakukan tentang uji kadar lemak pada daging lele dumbo dengan penambahan bubur buah nanas dapat disajikan sebagai berikut:

Tabel 3.Kadar lemak (\% $\mathrm{db}$ ) leledumbo padakonsentrasi buah nanas.

\begin{tabular}{|c|c|}
\hline Konsentrasi Bubur Buah Nanas $(\mathrm{g})$ & Lamak (\%db) \\
\hline 10 & $0.77 \mathrm{a}$ \\
15 & $0.73 \mathrm{a}$ \\
20 & $0.58 \mathrm{~b}$ \\
25 & $0.57 \mathrm{~b}$ \\
30 & $0.50 \mathrm{~b}$ \\
\hline
\end{tabular}

Keterangan: Hasil diatas merupakan rerata dari tiga ulangan. Angka yang diikuti dengan notasi huruf yang sama dalam satu kolom menandakan antara perlakuan tidak berbeda nyata pada taraf signifikan 5\%. 
Hasil analisis sidik ragam menunjukkan bahwa konsentrasi bubur buah nanas berpengaruh nyata terhadap kadar lemak daging lele dumbo dengan $(\mathrm{P}<0.50)$. Kadar lemak terendah pada daging lele dumbo dengan penambahan bubur buah nanas $30 \mathrm{~g}$ sebesar $(0.50 \% \mathrm{db})$ dan tertinggi terdapat pada penambahan bubur buah nanas $10 \mathrm{~g}$ (0.77 \% db).Menurut Shahidi dkk.(1995) dalamWijianti, dkk (2016) menjelaskan bahwa pada saat proses hidrolisis enzimatis terjadi perubahan struktur jaringan ikan yang sangat cepat sehingga menyebabkan kadar lemak menurun. Sedangkan setruktur membrane sel otot terlihat relatif resisten dari kerusakan. Pada saat proses hidrolisis. Membrane ini cenderung berkumpuldan membentuk gelembung yang tak larut, mengakibatkan hilangnya membrane lipid yang berdampak pada penurunan kadar lemak.

\section{Kadar Karbohidrat}

Hasil analisa statistika konsentrasi bubur buah nanas berpengaruh nyata pada nilai karbohidrat ikan lele dumbo $(\mathrm{P}>0.05)$. Ratarata nilai kadar karbohidrat $(\% \mathrm{db})$ daging lele dumbo dari masing-masing perlakuan dapat dilihat pada Tabel 4.

Tabel 4.Kadar karbohidrat (\%db) lele dumbo pada konsentrasi buah nanas.

\begin{tabular}{|c|c|}
\hline $\begin{array}{c}\text { Konsentrasi Bubur Buah Nanas } \\
(\mathrm{g})\end{array}$ & $\begin{array}{c}\text { Karbohidrat } \\
(\% \mathrm{db})\end{array}$ \\
\hline 10 & $1.88 \mathrm{~d}$ \\
15 & $2.84 \mathrm{c}$ \\
20 & $3.05 \mathrm{~b}$ \\
25 & $3.35 \mathrm{a}, \mathrm{b}$ \\
30 & $3.64 \mathrm{a}$ \\
\hline
\end{tabular}

Keterangan :Hasil diatas merupakan rerata dari tiga ulangan. Angka yang diikuti dengan notasi huruf yang sama dalam satu kolom menandakan antara perlakuan tidak berbeda nyata pada taraf signifikan 5\%.
Hasil analisis sidik ragam menunjukkan bahwa konsentrasi bubur buah nanas berpengaruh nyata terhadap kadar karbohidrat daging lele dumbo ( $\mathrm{P}<0.05$ ). Kadar karbohidrat terendah pada daging ikan lele dumbo dengan penambahan bubur buah nanas $10 \mathrm{~g}$ ( $1.88 \% \mathrm{db})$ dan tertinggi terdapat pada penambahan konsentrasi bubur buah nanas $30 \mathrm{~g} \quad(3.64 \% \mathrm{db})$. Rendahnya karbohidrat dalam hidrosilat daging lele dumbo.Menurut Okuzumi dan Fuji (2000) dalamWijianti, dkk (2016) bahwa kandungan karbohidrat dalam produk perikanan tidak mengandung serat pada umumnya, bentuknya glikogen dan dalam jumlah sedikit berupa glukosa, fruktosa, sukrosa, serta beberapa jenis monosakarida dan disakarida.

\section{Kadar Abu}

Berdasarkan hasil penelitian yang dilakukan tentang uji kadar abu pada hidrolisat daging leledumbo dengan penambahan bubur buah nanas dapat disajikan data sebagai berikut:

Tabel 5.Kadar abu (\% db) lele dumbo pada konsentrasi buah nanas.

\begin{tabular}{|c|c|}
\hline Konsentrasi Bubur Buah Nanas $(\mathrm{g})$ & Abu (\% db) \\
\hline 10 & $5.88 \mathrm{~b}$ \\
15 & $6.22 \mathrm{a}, \mathrm{b}$ \\
20 & $6.45 \mathrm{a}, \mathrm{b}$ \\
25 & $6.35 \mathrm{a}, \mathrm{b}$ \\
30 & $6.64 \mathrm{a}$ \\
\hline
\end{tabular}

Keterangan :Hasil diatas merupakan rerata dari tiga ulangan. Angka yang diikuti dengan notasi huruf yang sama dalam satu kolom menandakan antara perlakuan tidak berbeda nyata pada taraf signifikan $5 \%$.

Hasil analisis sidik ragam menunjukkan bahwa konsentrasi bubur buah nanas berpengaruh nyata terhadap kadar abu hidrosilat daging lele dumbo $(\mathrm{P}<0.05)$. Kadar abu terendah pada daging lele dumbo dengan penambahan bubur buah nanas $10 \mathrm{~g}$ (5.88 $\%$ db) sedangkan tertinggi terdapat pada 
penambahan bubur buah nanas $30 \mathrm{~g}$ (6.64 \%db).Menurut Gesualdo dan Li-Chan (1999) dalamWijianti, dkk (2016)menyatakan bahwa pencampuran senyawa asam dan alkali dalam larutan hidrolisat protein akan menyebabkan akan terbentuknya senyawa garam, sehingga dapat meningkatan kadr abu pada hidrosilat protein ikan lele.

\section{Rendemen Hidrosilat Protein Ikan Lele Dumbo}

Hasil analisas sidik ragam menunjukkan bahwa konsentrasi bubur buah nanas berpengaruh nyata terhadap rendemen hidrosilat daging lele dumbo $(\mathrm{P}<0.05)$. Hasil analisis sidik ragam menunjukkan bahwa daging lele dumbo $(\mathrm{P}<0.05)$ pada proses hidrolisis dengan mengunakan bubur buah nanas, subsrat yang di gunakan akan diubah menjadi produk hidrosilat. Presentase banyaknya produk hidrosilat yang dihasilkan terhadap berat bahan baku sebelum hidrolisis disebut rendemen produk hidrosilat. Terlarutnya komponen gizi seperti lemak, protein dan mineral selama proses hidrolisis mempengaruhi besarnya rendemen produk hidrosilat yang dihasilkan (Shahidi dkk., 1995 dalamWijianti dkk., 2016). Rendemen hidrosilat ikan lele dumbo dengan konsentrasi bubur buah nanas yang berbeda disajikan pada Tabel 6 .

Tabel 6.Rendemen hidrosilat lele dumbo pada konsentrasi buah nanas.

\begin{tabular}{|c|c|}
\hline Konsentrasi Bubur Buah Nanas (g) & Randemen (\%) \\
\hline 10 & $10.67 \mathrm{e}$ \\
15 & $12.63 \mathrm{~d}$ \\
20 & $13.92 \mathrm{c}$ \\
25 & $15.50 \mathrm{~b}$ \\
30 & $16.50 \mathrm{a}$ \\
\hline
\end{tabular}

Keterangan : Hasil diatas merupakan rerata dari tiga ulangan. Angka yang diikuti dengan notasi huruf yang sama dalam satu kolom menandakan antara perlakuan tidak berbeda nyata pada taraf signifikan $5 \%$.

\section{Uji Organoleptik}

Hidrosilat ikan lele dumbo yang di hasilkan dilakukan uji organoleptik warna, bau dan rasa.Hasil uji organoleptik hidrosilat protein ikan lele dumbo dapat dilihat pada Tabel 7.

Tabel 7. Uji organoleptik hidrosilat ikan lele dumbo.

\begin{tabular}{|c|c|c|c|c|c|c|}
\hline \multirow{2}{*}{$\begin{array}{l}\text { Tipe } \\
\text { uji }\end{array}$} & \multicolumn{5}{|c|}{ Penambahan Bubur Buah Nanas } & \multirow{2}{*}{$\begin{array}{l}\text { Ketera } \\
\text { ngan }\end{array}$} \\
\hline & $\begin{array}{l}10 \\
\mathrm{~g}\end{array}$ & $15 \mathrm{~g}$ & $20 \mathrm{~g}$ & $25 \mathrm{~g}$ & $30 \mathrm{~g}$ & \\
\hline warna & $\begin{array}{l}1 . \\
35 \\
c\end{array}$ & $\begin{array}{l}1.45 \\
\mathrm{c}\end{array}$ & $\begin{array}{l}1.65 \\
c\end{array}$ & $\begin{array}{l}2.5 \\
b\end{array}$ & $\begin{array}{l}3.15 \\
\mathrm{a}\end{array}$ & $\begin{array}{l}1 . \\
\text { Merah } \\
\text { muda } \\
2 . \\
\text { Merah } \\
3 . \\
\text { Merah } \\
\text { cerah } \\
4 . \\
\text { Merah } \\
\text { kecokl } \\
\text { atan } \\
5 . \\
\text { Kecokl } \\
\text { atan }\end{array}$ \\
\hline $\mathrm{Bau}$ & $\begin{array}{l}1 . \\
25 \\
d\end{array}$ & $\begin{array}{l}1.5 \\
\mathrm{c}, \mathrm{d}\end{array}$ & $\begin{array}{l}1.85 \\
a, b\end{array}$ & $\begin{array}{l}2.1 \\
b\end{array}$ & $\begin{array}{l}2.65 \\
a\end{array}$ & $\begin{array}{l}\text { 1. Bau } \\
\text { segar } \\
\text { 2. Bau } \\
\text { segar } \\
\text { Sepesi } \\
\text { fik } \\
\text { 3. } \\
\text { Kuran } \\
\text { g segar } \\
\text { 4. Bau } \\
\text { netral } \\
\text { 5. Bau } \\
\text { tengik }\end{array}$ \\
\hline Rasa & $\begin{array}{l}1 . \\
8 \\
d\end{array}$ & $\begin{array}{l}2.05 \\
d\end{array}$ & $\begin{array}{l}2.85 \\
\mathrm{c}\end{array}$ & $\begin{array}{l}3.45 \\
b\end{array}$ & $\begin{array}{l}3.85 \\
\mathrm{a}\end{array}$ & $\begin{array}{l}1 . \\
\text { Sangat } \\
\text { pahit } \\
2 . \\
\text { Pahit } \\
3 . \\
\text { Netral } \\
4 . \\
\text { Manis } \\
5 . \\
\text { Sangat } \\
\text { Manis }\end{array}$ \\
\hline
\end{tabular}


sama dalam satu kolom menandakan antara perlakuan tidak berbeda nyata pada taraf signifikan $5 \%$.

\section{Warna}

Warna salah satu parameter mutu yang langsung tertangkap oleh indra mata. Dari Tabel 7 menunjukkan bahwa perlakuan bubur buah nanas berpengaruh sangat nyata terhadap warna hidrolisat daging ikan lele dumbo.Semakin besar buah nanas yang di tabahkan warna hidrolisat ikan lele dumbo semakin merah. Menurut Lawrie (2003) dalam Ismanto dan Basuki (2017), warna daging dipengaruhi oleh beberapa faktor, termasuk, pakan, sepesies, bangsa, umur, jenis kelamin, stress (tingkat aktivitas dan tipe otot), $\mathrm{pH}$ dan oksigen. Fator-faktor tersebut dapat mempengaruhi faktor utama warna daging yaitu konsentrasi pigmen daging mioglobin.Hal ini disebabkan oleh terjadinya perubahan kondisi oksidasi mioglobin yang menyebabkan perubahan warna daging.Mioglobin dapat mengalami perubahan bentuk akibat berbagai reaksi kimia bila terkena udara, pigmen mioglobin akan teroksidasi menjadi oksimioglobin yang mengeluarkan warna merah terang.

\section{Bau}

Berdasarkan hasil uji organoleptik pada Tabel 7, menunjukkan bahwa perlakuan penambahan bubur buah nanas berpengaruh sangat nyata terhadap bau hidrolisat protein daging ikan lele dumbo yang dihasilkan. Semakin besar penambahan bubur buah nanas, maka bau hidrolisat daging ikan lele dumbo dari bau segar sampai kurang segar. Hal itu kemungkinan disebabkan karena kadar lemak pada bahan baku ikan lele dumbo rendah, sehingga proses oksidasi lemak selama proses hidrolisis juga tidak menghasilkan bau tengik yang tajam. Proses hidrolsis lemak juga menghasilkan komponen yang dapat menimbulkan bau amis pada daging ikan lele dumbo. Pada reaksi hidrolisis lemak, lemak diubah menjadi asam lemak bebas (ALB) dan gliserol (Ismanto dan Basuki., 2017). Pembentukan asam lemak bebas tidak mempengaruhi nilai gizi pada ikan, tetapi nilai asam bebas dapat diguakan untuk mengetahui tingkat ketengikan ikan (Aubourg,2001dalam Ismanto dan Basuki ., 2017).

\section{Rasa}

Berdasarkan uji organoleptik pada Tabel 7,menunjukkan bahwa perlakuan penambahan bubur buah nanas berpengaruh sangat nyata terhadap rasa hidrolisat protein daging ikan lele dumbo yang dihasilkan. Semakin besar penambahan bubur buah nanas, maka rasa hidrolisat daging ikan lele dumbo dari pahit sampai manis. Rasa pahit pada produk hidrolisat merupakan ciri khas produk hidrolisat protein ikan yang disebabkan oleh pembentukan peptida berantai pendek sebagai produk hasil pemecahan protein.Mekanisme terjadinya komponen penyebab rasa pahit tersebut tidak dapat diprediksi karena berbagai faktor yang sangat komplek berperan dalam pembentukan komponen penyebab rasa pahit tersebut (Aubes-Dufan dkk., 1995 dalam Ismanto dan Basuki., 2017). Sedangkan rasa manis pada hidrolisat protein ikan kemungkianan disebabkan oleh terbentuknya asam amino glisin selama proses hidrolisis, sedangkan rasa gurih disebabkan oleh pembentukan oligopeptida yang mempunyai proporsi molaritas yang tinggi dari asam glutamat selama proses hidrolisis (Barzana and GarcisGaribay, 1994 dalam Ismanto dan Basuki.,2017). 


\section{KESIMPULAN}

Hidrolisat protein ikan lele dumbo dapat dihasilkan melalui hidrolisis enzimatis mengunakan enzim bromelin dari buah nanas.Konsentrasi bubur buah nanas berpengaruh nyata terhadap kadar air, protein, lemak, karbohidrat dan abu. Kondisi optimum untuk menghidrolisis daging ikan lele dumbo menjadi hidrolisat protein adalah konsentrasi bubur buah nanas $20 \mathrm{~g}$, kadar air $80.81 \%$, kadar protein $72.04 \%$ db, kadar lemak $0.58 \% \mathrm{db}$, karbohidrat $3.05 \% \mathrm{db}$, kadar abu $13.92 \%$ db, warna hidrolisat merah (1.65), bau segar spesifik (1.85), dan rasa netral (2.85).

\section{DAFTAR PUSTAKA}

Firman Sebayang, 2006, Pengujian Stabilitas Enzim Bromelin Yang Di Isolasi Dari Bonggol Nanas Serta Imobilisai Menggunakan Kappa Karrangenan. Medan:Universitas Sumatra Utara.

Selamet Sudarmadji, Bambang Haryono Dan Suhardi, 1989, Prosedur Annalisa Bahan Pangan, Liberty, Yogyakarta.

Pigot, G.M. \& Tucker, B. W, 1990, Untility Fish Flesh Effectively While Maintaining Nutritional Qualitie, Seafood Effectof Technologyon Nutritional, Mercel Deker, New York.

Wijianti, I, Romadhon Dan Laras Rianingsih. 2016. Karakteristik Hidrosilat Protein Ikan Bandeng ( ChanosChanosForsk) Dengan Konsentrasi Dengan Konsentrasi Enzim Bromelin Yang Berbeda. Jurnal Saintek Perikanan Vol.11 No. 2:129-133, UNDIP Semarang.
Ismanto dan Basuki (2017), Pemanfaatan Ektrak Buah Nanas Dan Ektrak Buah Papaya Sebagai Pengempuk Daging Ayam Parent Stock Afkir, Jurnal Perternakan Sriwijaya, Vol. 6, No.2 